\title{
"An empirical study of optimal access to external finance by small and medium enterprise start-ups"
}

\begin{tabular}{|c|c|}
\hline \multirow{5}{*}{ AUTHORS } & Herman Bamata (D https://orcid.org/0000-0002-9199-3540 \\
\hline & Krishna K. Govender (D https://orcid.org/0000-0002-3079-5989 \\
\hline & $\mathbb{R}$ http://www.researcherid.com/rid/U-1710-2017 \\
\hline & Ziska Fields (D https://orcid.org/0000-0001-5353-1807 \\
\hline & $\mathbb{R}$ http://www.researcherid.com/rid/D-1827-2012 \\
\hline ARTICLE INFO & $\begin{array}{l}\text { Herman Bamata, Krishna K. Govender and Ziska Fields (2019). An empirical } \\
\text { study of optimal access to external finance by small and medium enterprise start- } \\
\text { ups. Problems and Perspectives in Management, 17(3), 242-258. } \\
\text { doi:10.21511/ppm.17(3).2019.20 }\end{array}$ \\
\hline DOI & http://dx.doi.org/10.21511/ppm.17(3).2019.20 \\
\hline RELEASED ON & Friday, 23 August 2019 \\
\hline RECEIVED ON & Monday, 05 November 2018 \\
\hline \multirow[t]{2}{*}{ ACCEPTED ON } & Wednesday, 27 February 2019 \\
\hline & $((c))_{E Y}$ \\
\hline LICENSE & $\begin{array}{l}\text { This work is licensed under a Creative Commons Attribution } 4.0 \text { International } \\
\text { License }\end{array}$ \\
\hline JOURNAL & "Problems and Perspectives in Management" \\
\hline ISSN PRINT & $1727-7051$ \\
\hline ISSN ONLINE & $1810-5467$ \\
\hline PUBLISHER & LLC "Consulting Publishing Company "Business Perspectives" \\
\hline FOUNDER & LLC "Consulting Publishing Company "Business Perspectives" \\
\hline
\end{tabular}

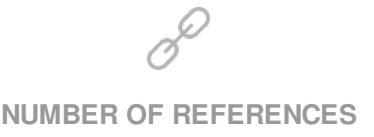

62

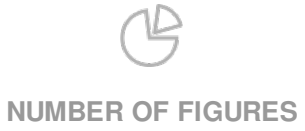

2
NUMBER OF TABLES

7

(C) The author(s) 2023. This publication is an open access article. 


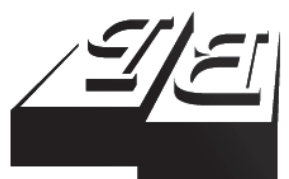

BUSINESS PERSPECTIVES

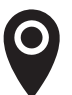

LLC "CPC "Business Perspectives" Hryhorii Skovoroda lane, 10, Sumy, 40022, Ukraine

www.businessperspectives.org

Received on: $5^{\text {th }}$ of November, 2018 Accepted on: $27^{\text {th }}$ of February, 2019

(C) Herman Bamata, Krishna K. Govender, Ziska Fields, 2019

Herman Bamata, Ph.D. Student, School of Management, IT and Governance, University of KwaZuluNatal, South Africa.

Krishna K. Govender, Professor, School of Management, IT and Governance, University of KwaZuluNatal, South Africa.

Ziska Fields, Professor, School of Management, IT and Governance, University of KwaZulu-Natal, Durban, South Africa.

\section{(ㄷ)(i)}

This is an Open Access article, distributed under the terms of the Creative Commons Attribution 4.0 International license, which permits unrestricted re-use, distribution, and reproduction in any medium, provided the original work is properly cited.
Herman Bamata (South Africa), Krishna K. Govender (South Africa),

Ziska Fields (South Africa)

\section{AN EMPIRICAL STUDY OF OPTIMAL ACCESS TO EXTERNAL FINANCE BY SMALL AND MEDIUM ENTERPRISE START-UPS}

\begin{abstract}
The aim of this study is to empirically examine the relationships between the determinants of start-up SME success, namely start-up awareness and management skills, and the finance suppliers. This study has proposed a framework that improves the ability of start-up SMEs to access external finance. Through descriptive and inferential statistical analyses of data from a survey of a sample of SMEs in South Africa, it was ascertained that the framework which maps the entrepreneur's start-up awareness and requisite management skills with the finance providers' requirements will make up a tool to assist start-up SMEs in developing optimal financing options to grow their businesses.
\end{abstract}

\section{Keywords SME start-up, start-up awareness, management skills \\ JEL Classification M13}

\section{INTRODUCTION}

Although there is financial support for SMEs, access to the various sources of finance remains problematic and a challenge for SME start-ups. The various reasons being inter alia, a high rate of business failure, lack of collaterals, and lack of awareness of available support programs by start-up entrepreneurs should be noted. In light of the above, the aim of this study is to empirically examine the relationships between the determinants of start-up SME success, namely start-up awareness and management skills, and the finance suppliers. Three external sources of finance for SME start-ups are explored, namely, Government grants, commercial bank funds, and private equity finance. Respectively identified as Government source of Finance (GF), Corporate source of Finance (CF), and Personal/Social source of Finance (PSF). The funding requirements of these financial institutions are identified and analyzed, and a framework is proposed that improves the ability of start-up SMEs to access external finance.

\section{LITERATURE REVIEW}

Small and medium-sized enterprises (SMEs) continue to play a critical role in the economic growth of most countries (Lekhanya, 2016), and small businesses have been central in the development of several developing countries, often serving as the primary source of livelihood (Bongini, Ferrando, Rossi, \& Rossolin, 2017, p. 2). According to Domeher, Abdulai, and Yeboah (2016, p. 165), SMEs account for over $60 \%$ of the GDP and over $70 \%$ of total employment in low-in- 
come countries; over $95 \%$ of total employment and about $70 \%$ to the GDP of middle-income countries. The European Central Bank (2013) reported that SMEs are the backbone of the Euro area economy, since they constitute about $98 \%$ of all Euro area firms, employ around $75 \%$ of the Euro area employees and generate around $60 \%$ of value added (Coeré, 2013, p. 1). The SME sector also acts as an absorbent of retrenched people coming from the private and public sector (Smit, 2012).

Most small businesses in South Africa (SA) do not progress beyond the 'Start-up' phase, and their $75 \%$ failure rate is one of the highest in the world (Fatoki \& Garwe, 2010; Bisseker, 2014; Wagner, 2015). SMEs in SA are expected to be an important vehicle to address the challenges of job creation, sustainable economic growth, equitable distribution of income and the overall stimulation of economic growth (Ayandibu \& Houghton, 2017, p. 136). The SA government through the Department of the Presidency and the National Planning Commission, launched the National Development Plan (NDP) 2030, which aims to eliminate poverty and reduce inequality by 2030 (Manuel, 2012). Although priority is given to enabling SMEs to access banking services, SA banks do not extend sufficient credit to smaller firms (Manuel, 2012).

Rupeika-Apoga and Solovjova (2017) argued that during the past three years in general, access to finance for start-up SMEs has improved, nevertheless wide divergences remain across the euro area countries. According to European Central Bank (2016), access to finance remained the dominant concern for SMEs in Greece $(31 \%$,), while $13 \%$ of SMEs in Italy and $12 \%$ in both Ireland and the Netherlands named access to finance as the most important problem, compared with only around $6 \%$ of SMEs in both Austria and Germany and 8\% in Finland. In Latvia in 2016, the most important problems faced by SMEs were finding customers (20\%), availability of skilled staff or experienced managers (15\%), competition (13\%), costs of production or labor (12\%) and finally access to finance with $10 \%$ as the fifth most pressing obstacle (Kwaak \& Zeijden, 2016).

Many determinants are considered for the purpose of explaining the challenges of accessing ex- ternal finance by start-up SMEs. In the context of $\mathrm{UK}$, it is believed that access to finance by SMEs is closely affected by the differences in commercial banks or the practices and the policies of the supply side of finance. It is argued that most of the commercial banks in UK differ in terms of the relationship between those lending institutions and the entrepreneur (Osano \& Languitone, 2016). A number of factors have been identified by the World Bank (2003) that constitute constraints by start-up SMEs to access external finance. These factors include distortions of financial sectors, lack of know-how on the finance supply side, information asymmetry (access to business information), and the high risk in lending to Start-up SMEs.

The study conducted by Beck (2007) ascertained that the weaknesses in financial and legal systems in the developing countries constitute an obstacle in accessing finance products. When Beck analyzed 70 developing countries, he further concluded that the local government has actually the entire responsibility to build finance institutions, and market activities should be undertaken in friendly manner in order to provide a proper regulatory framework to reduce financial constraints by start-up SMEs.

Small business ventures in SA are fraught with uncertainties, and limited knowledge is available in this area because of the complex relationship between the determinants of start-up business success and access to external finance by SMEs (Chawla, Khanna, \& Chen, 2010, p. 2; Fatoki \& Odeyemi, 2010). The aforementioned has, however, not prevented managerial prescriptions from being devised on what to do and which determinants to use in order to improve access to external finance for these organisations (Simpson, Padmore, \& Newman, 2011, p. 265).

Although it is reasonable to expect finance providers to require that certain fundamentals or indicators (determinants) of business success be in place before considering granting finance to SMEs, there is no general consensus on the determinants of business success. Katwalo (2010, p. 140) suggested that a determinant of start-up business success is any competitive asset or competence that is needed to win in the market place, whether it is a strategic competitive advantage, represent- 
ing a sustainable advantage or merely parity with the firm's competitors. The list of determinants of start-up business success can be very exhaustive, however, for this study 22 (Table 1) are examined (Doom, Milis, Poelmans, \& Bloemen, 2009; Fatoki \& Odeyemi, 2010; Smorfitt, 2008).

Table 1. Determinants of start-up business success

Source: Own compilation.

\begin{tabular}{|c|c|c|c|}
\hline \multicolumn{2}{|r|}{ Start-up awareness } & \multicolumn{2}{|r|}{ Management skills } \\
\hline 1 & Opportunity awareness & 1 & General management skills \\
\hline 2 & Differentiating factors & 2 & $\begin{array}{l}\text { Strategic management } \\
\text { skills }\end{array}$ \\
\hline 3 & Business model & 3 & Organizational skills \\
\hline 4 & Strategy & 4 & Technical skills \\
\hline 5 & Feasibility study & 5 & $\begin{array}{l}\text { Financial management } \\
\text { skills }\end{array}$ \\
\hline 6 & Business plan & 6 & Leadership skills \\
\hline 7 & Location & 7 & Communication skills \\
\hline 8 & Amount of seed capital & 8 & $\begin{array}{l}\text { Inventory management } \\
\text { skills }\end{array}$ \\
\hline 9 & Source of seed capital & 9 & Marketing skills \\
\hline \multirow[t]{3}{*}{10} & Decision-making ability & 10 & $\begin{array}{l}\text { Contingency management } \\
\text { skills }\end{array}$ \\
\hline & & 11 & Controls and systems skills \\
\hline & & 12 & Growth oriented skills \\
\hline
\end{tabular}

It is against the above background that this study investigates the relationship between the determinants of the success of start-up SMEs and their access to external financing in the SA context, with the intention of developing a Framework for these SMEs to access external finance. More specifically, the relationship between the SME owner-managers' "start-up awareness" and their access to external sources of start-up finance, as well as the relationship between the SME owner-managers' management skills and their access to external sources of start-up finance, will be empirically explored using inferential statistical techniques to analyze survey data.

\section{DETERMINANTS OF SME SUCCESS}

\subsection{Start-up awareness}

As reflected in Table 1, the business is likely to fail if there is a lack of opportunity, since a good idea is not enough to make profit within an existing market (Short et al., 2010, p. 40; Chell, 2013, p. 11).
After understanding the business opportunity, the entrepreneur will define the way he/she can gain a competitive advantage in the market. Furthermore, as reflected in Table 1, the business model is critical, since it will reflect a tentative thought on how it will deliver "what value" and "to whom". The fundamental strategic question that will be raised is how does the entrepreneur build sustainable competitive advantage and make abnormal profit? According to Teece (2010), a business strategy conceived as "think out in advance, is valid only in some cases, in which the business model is a complex system that has been conceived in advance". Abraham (2013, p. 31) opined that "while the business model determines who the company's customers are, and how to make profit by providing value, business strategy will look at how the company will beat its competitors through differentiation". Therefore, a business strategy will require more analysis, calculations and choices that is reliable information available in the entrepreneur's hands (Philipson, 2016, p. 2). Blackburn, Hart, and Wainwright $(2013$, p. 11) argued that "small businesses are likely to use strategies that emerge over time and are flexible and unconstrained. Business planning is more likely to be considered in small businesses than just developing a written document for strategy formulation. A good strategy, resulting from a proper planning process, is necessary for keeping high performances and preserving success (Braun, Latham, \& Porschitz, 2016, p. 3; Ghezzi, 2013, p. 1327). However, due to change, strategy should be adaptive or of resilient nature, which will create endogenous innovation or catch up exogenous changes, so as to maintain an adequate strategic fit between the firm's strategy and the surrounding internal and external environments (Louw \& Venter, 2013, p. 179; Ghezzi, 2013 , p. 1327). In addition, sometimes change is not only incremental, it is configured as a discontinuity which radically departs from the original state and introduces unexpected, unplanned and often dramatic variations (Louw \& Venter, 2013, p. 179; Ghezzi, 2013, p. 1327).

A viability study includes market research, which serves the company to ensure the existence of demand for the new product or service, and it would determine if the market is large enough and if the competitive sphere will easily accommodate the new product or service. A viability study will 
assist the company define its marketing strategy (Greene, 2008). Schiraldi and Silva (2012, p. 7) pointed out that although "a business plan is a compulsory requirement for loan applications or co-investors, it is an important instrument for internal management".

After establishing the plan and strategy of the start-up business, the entrepreneur needs to solve the issue of seed capital, inter-alia, the amount and source, which are very important in starting a business. An incorrect source of seed capital will lead to inability to raise finance, and consequently business failure (Burke, 2006; Mmako et al., 2017).

Fatoki and Odeyemi (2010, p. 131) noted that market potential and growth opportunities are also influenced by the location of a new business. Freeman and Style (2014, p. 182) pointed out that "geographical location implications on the new firm exist in its access to markets and resources".

\subsection{Management skills}

Fatoki and Odeyemi (2010, p. 2766) examined the importance of management competencies in the success of SME start-ups and found that lack of managerial experience, skills and personal qualities as well as other determinants such as adverse economic conditions, poorly thought out business plans and resource starvation are the main reasons why SME start-ups fail. According to Chell (2013, p. 7), entrepreneurship and innovation skills are likely to be specific to those activities, and aim to produce particular outcomes, which vary from business funding, growth and sustainability of an enterprise. The SME start-up will, therefore, be capable of developing innovative products and services, enabling enterprises to compete locally, nationally or globally (Chell, 2013, p. 7; Gill \& Bigger, 2012, p. 658).

Dane and Pratt (2007, p. 33) emphasized that decision-making skills enable the entrepreneur to make both fast and appropriate decisions in the organization. Obiajunwa (2013, p. 65) stated that the lack of technical skills or related experience in the chosen business also has an enormous impact on the ability of the business to succeed. Thus, the SME owner-managers should have adequate technical skills and a good working knowledge of the business. The acquisition of sufficient knowledge of the technology of the business is necessary to enable the managers to understand all aspects intelligently (Obiajunwa, 2013, p. 65).

Nieuwenhuizen (2011, p. 64) stated that financial management skills and systems are important criteria in the ongoing success of a business, and key to these skills is the ability to interpret financial statements. Nieuwenhuizen $(2011$, p. 38) and Mmako et al. (2017, p. 73) pointed out that a lack of leadership skills can be crucial in a SME, where the entrepreneur might be the only manager at the enterprise, leading to poor management of staff. Leadership skills in any business are critical, but at a SME, individual leadership skills play an even more important role due to the lower numbers of managers in the organization. Entrepreneurs are not by default great leaders or managers, they, therefore, need to do a detailed self-assessment and gain the skills required to fill the gaps in his/ her skills portfolio (Kearns et al., 2015, p. 713).

According to Jones and George (2015), the ability to create demand for the businesses' products or services is totally dependent on how well the business communicates. Communication systems, such as e-mail, are also critically important in any communication system today, and the use of intranet and extranet systems will also enhance the firm's communication and information systems (Westhead, Wright, \& McElwee, 2011). Bambacas and Patrickson $(2009$, p. 111) suggested that "the ability to manage staff is closely related to communication, management and leadership skills". Those who are managing a small group of subordinates are expected to have good personal communication which later builds to effective relationships in growing business, and establishing trust, credibility and high integrity as they progress to the latter part of their businesses (Bambacas \& Patrickson, 2009, p. 111).

According to Swart (2013), inventory management skills include financial and inventory controls. Uncontrolled growth, together with poor financial and inventory control, are also major contributory factors to business failure, and poor controls within a business lead directly to business failure (Burke, 2006). Bushuev et al. (2015, p. 285) further observed that "key segments of the total 
problem area such as managing information and uncertainty and the integration of inventory and production planning systems have still been overlooked by researchers".

Jones and George (2015) pointed out that marketing skills in a business are critical to the success of every business, as are contingency management skills, which allow the owner to adapt to ever changing circumstances. There will also be a greater requirement for contingency management in that small and medium businesses are not market leaders or market challengers but market followers and market niches (Bamata 2013). Thus, they need to change in response to changing circumstances within their environment more than the market leader would need to and, would often have to change in response to changes implemented by the market leader (Smorfitt, 2008, p. 46).

Management control systems are vehicles for organizations to achieve their goals by securing organizational conformity with underlying social expectations, which is the source of legitimacy and resources (Schäffer, Strauss, \& Zecher, 2015, p. 395). According to Swart (2013), in the current information age, in which businesses find themselves, systems that meet the current and future needs for information are essential components in a firm's portfolio of criteria for success. Too many firms have a reactive response, rather than a proactive strategy, to the implementation of information technology. These integrated systems need to include an accounting function, a sales management function, communication systems (e-mail) and a marketing intelligence management system (Mariotti \& Greene, 2014).

\subsection{SME financing options and challenges in South Africa}

According to Azeem and Chughtai (2013, p. 144), the financing needs of SMEs is during three stages, namely, start-up, expansion and rehabilitation. The focus in this study is on the start-up phase, since many businesses fail at this stage due to inter-alia, lack of finance. According to Irwin and Scott (2010, p. 245), large firms have the advantage of accessing the capital market and getting quick financing at low cost, but this is not the case with SMEs in SA. Sources of finance for SMEs are very minimal, which compels them to rely on finance from government grants, bank loans and private sources. The requirements of lending institutions do not exactly match the ability of SMEs by making it tougher to get financing at appropriate and affordable terms and conditions (Abor \& Biekpe, 2009, p. 84). The SA government launched different entities through the Department of Trade and Industry (DTI), Small Development Agency (SEDA), NPO and donors, to boost the performance of SME sector. However, Smit and Watkins (2012, p. 6326) opined that although sufficient funds have been made available by the SA government for SME support, access remains problematic, especially for SMEs at the startup phase. Furthermore, significant number of startup businesses applications for external finance are declined.

The 2010 FNB and Endeavor Report (2010, p. 15) indicated that the issue is not so much a lack of access to capital but the stringent and lengthy process required to access external funding. This is exacerbated by the general lack of awareness about the procedures and the courses of action involved in gaining equity funding, which leaves entrepreneurs under-prepared and under-researched. The application process tends to be bureaucratic and heavily laden with protocols and red tape as funders endeavor to gain confidence and assurance when granting funding to entrepreneurs (FNB \& Endeavor, 2010, p. 15).

With a better understanding and use of the Financing Framework for star-up SME's access to external finance, it is possible to draw a more realistic picture of the financing needs of SA SMEs, with due consideration of the three main sources of external finance, namely, government, commercial banks and private equity (Burke, 2006, p. 117).

\subsection{Conceptual model and hypotheses development}

Uvar and Guzelyurt $(2015$, p. 286$)$ suggested that the lack of finance is one of the major issues influencing the establishment and development of SME start-ups in SA. Thus, this indicates the presence of a significant gap in the existing and preferable finance options for SME startups. The choice of a type of external finance is 
so important that most small business failures are attributed to its inadequacy or inappropriateness (Kumar \& Rao, 2015, p. 100). Since small firms differ from large firms in several respects, they use different financing options and methods. Unlike large and publicly traded businesses, SMEs have limited or no access to certain types of external financing such as long-term debt and issuing equity. They, therefore, are more dependent on short-term debt in many cases (Uyar \& Guzelyurt, 2015, p. 286).

The above scenarios justify the need for developing a framework for SMEs to access external finance, which framework must be built on a combination of the determinants of an entrepreneur's business awareness and management skills, with business processes that lead to preferable external finance options for SMEs. As financing needs and options change with the size and age of a firm, it becomes imperative to design a framework that can provide guidelines for the identification and analysis of business success factors that would improve SME access to external finance during start-up phase. Sources of external finance for SME start-ups include finance from the South African government grants, commercial bank finance and private equity finance. Therefore, to evaluate the link between the determinants of business success and access to external finance by SME start-ups, it is hypothesized that:

H1: There is a relationship between start-up awareness and management skills.

H2: $\quad$ There is a positive relationship between startup awareness and the choice of personal/social networks as a source of finance.

H3: There is a positive relationship between startup awareness and the choice of government as a source of finance.

H4: There is a positive relationship between startup awareness and the choice of corporate as a source of finance.

H5: There is a positive relationship between management skills and the choice of personal/social networks as a source of finance.
H6: There is a positive relationship between management skills and the choice of government as a source of finance.

H7: There is a positive relationship between management skills and the choice of corporate as a source of finance.

The above hypothesized relationships will be empirically examined using the methodology described below.

\section{RESEARCH METHODOLOGY}

Although there are three main research approaches, namely quantitative, qualitative and mixed methods research (Sedmak \& Longhurst, 2010 , p. 81), in this study, a quantitative approach was adopted, since this is the only way to test the various hypotheses postulated. The targeted population is all SME owners and managers in Pietermaritzburg, and the population is members of the Pietermaritzburg Chamber of Business (PCB), which is a registered NPO affiliated to the SA Chamber of Commerce and Industry (SACCI). Government and non-government organizations, schools and honorary members of PCB were excluded, which resulted in the population being reduced to 678 , from which a random sampling of 252 participants were selected.

A questionnaire was used to collect primary data from a sample of 252 respondents from different SME start-ups. The researcher hired and trained a fieldworker who visited the premises of the selected participants in Pietermaritzburg and personally handed questionnaire. The participants were requested to return the completed questionnaires by e-mail, after a week, and where this was not done, the fieldworker travelled to the premises of the non-compliant respondents and collected the questionnaire, as well as answered any queries the respondents may have had. During the two-month period of field research, the researcher and the fieldwork managed to collect 253 completed questionnaires. The Statistical Package for the Social Sciences (SPSS) version 24 was used to analyze the responses from the structured questionnaires. 


\section{FINDINGS}

\subsection{Reliability}

The reliability of the measurement instruments was assessed using both the Cronbach's alpha coefficients and composite reliability (CR) indicators. According to Kipkebut (2010), values for Cronbach's alpha range between 0 and 1 , and Hair et al. (2009) indicated that values higher than 0.6 were considered as being reliable. In the current study, the lowest Cronbach's Alpha value was 0.688 , while the highest value was 0.929 , which indicates that the Cronbach's alpha values exceeded the recommended threshold of 0.6 , hence, authenticating that the measures that were used in the study were all reliable as presented in Table 2.

Ramayah et al. (2011) indicated that the CR indicators show the extent to which research variables identify the latent variable. Urbach and Ahlemann (2010) posited that CR values that are acceptable are normally between zero and one, and according to Vicente, Abrantes, and Teixeira (2015), it is recommended that $\mathrm{CR}$ values must exceed 0.7 . The $\mathrm{CR}$ test result was calculated using the following formula:

$$
C R \eta=\frac{\left(\sum \lambda y_{i}\right) \cdot 2}{\left[\left(\sum \lambda y_{i}\right) \cdot 2+\left(\sum \varepsilon_{i}\right)\right]} .
$$

$C R=$ (square of the summation of the factor loadings)/\{(square of the summation of the factor loadings) + (summation of error variances)\}.

The current study's lowest $C R$ value was 0.701 , while the highest was 0.941 . Table 1 reflects the $C R$ values, which were all greater than 0.7 , thus further confirming the reliability of the measures.

\subsection{Validity}

Table 1 presents the estimates of the factor loadings/standardized regression weights that were all greater than 0.5 , showing greater convergent validity. The lowest loading or regression weight was 0.522 , representing corporate finance $(\mathrm{CF})$, while government finance (GF) had the highest value among the loadings with 0.950 . This result indicates that all the measurement instruments used in this study explained at least $52 \%$ of what they are supposed to measure.

The thresholds presented in Table 2 ranged from 0.500 to 0.615 , which is consistent with that of Fraering and Minor (2006) and Hair et al. (2006). The values were calculated using Amos software and these were again cross-checked with manual calculations using the formula below, which resulted in same values.

$$
V \eta=\frac{\sum \lambda y_{i} \cdot 2}{\sum \lambda y_{i} \cdot 2+\sum \varepsilon_{i}} .
$$

$A V E=\{$ (summation of the squared of factor loadings) $/\{$ (summation of the squared of factor loadings) + (summation of error variances) $\}$. The AVE values greater than 0.5 further confirmed convergent validity of the research constructs.

Inter-construct correlation matrices and Average Variance Extracted (AVE) compared to Shared Variance (SV) were used to assess the discriminant validity in the current study. The discriminant validity of the study was examined through an examination of the correlation values of the research constructs. A low correlation between research constructs indicates that the research constructs are unique and distinct from one another, while the reverse indicates the absence discriminant validity. Theoretically, a correlation value less than 0.6 is deemed an indicator of discriminant validity. However, practically, a correlation value that is less than 0.85 is still regarded as marginally acceptable (Chinomona, 2011). As reflected in Table 2, the highest correlation value is 0.407 , hence, confirming the existence of discriminant validity of the research constructs used in the current study.

Table 2. Correlation between the constructs

\begin{tabular}{l|c:c:c:c:c}
\hline Research constructs & SUA & MS & PSF & GF & CF \\
\hline SUA & 1.000 & - & - & - & - \\
\hdashline MS & 0.173 & 1.000 & - & - & - \\
\hdashline PSF & 0.243 & 0.407 & 1.000 & - & - \\
\hdashline GF & 0.228 & 0.155 & 0.404 & 1.000 & - \\
\hdashline CF & 0.338 & 0.362 & 0.182 & 0.018 & 1.000 \\
\hline
\end{tabular}

Note: $* *$ Correlation is significant at the 0.01 level (2-tailed). SUA = start-up awareness, $\mathrm{MS}=$ management skills, PSF = personal/social source of finance, and GF = government source of finance, $C F=$ corporate source of finance. 
Table 3. Scale accuracy

\begin{tabular}{|c|c|c|c|c|c|c|c|c|}
\hline \multicolumn{2}{|c|}{ Research constructs } & \multicolumn{2}{|c|}{ Scale item } & \multirow{4}{*}{$\begin{array}{c}\begin{array}{c}\text { Cronbach's } \\
\text { test }\end{array} \\
\alpha \text { value } \\
0.720\end{array}$} & \multirow{4}{*}{$\begin{array}{c}\text { CR } \\
0.744\end{array}$} & \multirow{4}{*}{$\begin{array}{c}\text { AVE } \\
0.555\end{array}$} & \multirow{4}{*}{$\begin{array}{c}\begin{array}{c}\text { Highest shared } \\
\text { variance }\end{array} \\
0.167\end{array}$} & \multirow{3}{*}{$\begin{array}{c}\begin{array}{c}\text { Factor } \\
\text { loadings }\end{array} \\
0.722\end{array}$} \\
\hline & & \multirow{2}{*}{$\frac{\text { Mean }}{3.296}$} & \multirow{2}{*}{$\frac{\text { SD }}{0.971}$} & & & & & \\
\hline PSE & PSF2 & & & & & & & \\
\hline rJז & PSF7 & 2.510 & 0.872 & & & & & 0.767 \\
\hline \multirow{8}{*}{ SUA } & SUA1 & 3.122 & 1.365 & \multirow{8}{*}{0.880} & \multirow{8}{*}{0.907} & \multirow{8}{*}{0.553} & \multirow{8}{*}{0.114} & 0.847 \\
\hline & SUA2 & 3.449 & 0.991 & & & & & 0.581 \\
\hline & SUAB & 2.980 & 1.205 & & & & & 0.812 \\
\hline & SUA4 & 3.306 & 1.265 & & & & & 0.825 \\
\hline & SUA5 & 3.418 & 1.221 & & & & & 0.717 \\
\hline & SUA6 & 2.908 & 1.220 & & & & & 0.857 \\
\hline & SUAS & 4.184 & 0.460 & & & & & 0.648 \\
\hline & SUA9 & 3.643 & 0.872 & & & & & 0.600 \\
\hline \multirow{10}{*}{ MS } & MS1 & 4.051 & 0.734 & \multirow{10}{*}{0.929} & \multirow{10}{*}{0.941} & \multirow{10}{*}{0.616} & \multirow{10}{*}{0.167} & 0.796 \\
\hline & MS2 & 3.735 & 0.964 & & & & & 0.902 \\
\hline & MS3 & 3.796 & 0.936 & & & & & 0.846 \\
\hline & MS5 & 3.745 & 0.863 & & & & & 0.765 \\
\hline & MS6 & 4.143 & 0.760 & & & & & 0.756 \\
\hline & MS7 & 4.153 & 0.553 & & & & & 0.593 \\
\hline & MS8 & 3.643 & 0.413 & & & & & 0.808 \\
\hline & MS9 & 3.755 & 0.884 & & & & & 0.783 \\
\hline & MS10 & 3.571 & 0.783 & & & & & 0.774 \\
\hline & MS11 & 3.480 & 0.782 & & & & & 0.792 \\
\hline \multirow{2}{*}{ GF } & GF1 & 3.857 & 0.515 & \multirow{2}{*}{0.792} & \multirow{2}{*}{0.901} & \multirow{2}{*}{0.820} & \multirow{2}{*}{0.163} & 0.859 \\
\hline & GF2 & 3.857 & 0.440 & & & & & 0.950 \\
\hline \multirow{2}{*}{$\mathrm{CF}$} & CF1 & 3.796 & 0.606 & \multirow{2}{*}{0.688} & \multirow{2}{*}{0.701} & \multirow{2}{*}{0.504} & \multirow{2}{*}{0.114} & 0.522 \\
\hline & CF5 & 3.857 & 0.201 & & & & & 0.722 \\
\hline
\end{tabular}

Note: $*$ Scores: 1 - strongly disagree, 3 - moderately agree, 5 - strongly agree.

The discriminant validity was further verified by comparing the AVE and HSV (highest shared variance) by comparing either the AVE with the HSV or through a comparison of the square root of the AVE for each construct and its relationship with other constructs (Fornell \& Larcker, 1981, p. 337). The HSV which was determined by squaring the highest shared correlation value among constructs is reflected in Table 3. A construct that is unique and distinct from other research constructs is expected to have HSV, which is less than its Average Variance Extracted (AVE) (Chinomona, 2011). As can be noted from the results in Table 3, the HSV are all less than the AVE coefficients, hence confirming the existence of discriminant validity. Alternatively, as suggested by Fornell and Larcker (1981, p. 337), discriminant validity was also achieved when a square root of an AVE for each research construct was found to be greater than the correlation with the other construct, showing that discriminant validity has been achieved. Table 3 provides a summary of the descriptive statistics and the measurement model assessment statistics. The mean values provided below indicate that the majority of the respondents agreed with the measures asked $(>3-<5)$. The standard deviations were less than 2 , therefore, indicating that the mean values are a correct reflection of the majority average perceptions.

\subsection{Model fit summary}

Unlike the covariance based approach, which provides the absolute fit indices, incremental fit indices as well as the parsimony fit indices (Hair et al. 2010:665), Smart PLS provides limited model fit indices. These are Chi-square $\chi^{2} / \mathrm{df}$ ), the Normed Fit Index (NFI), and the Goodness-of-Fit Index (GFI), which are manually calculated based on a formula provided by Tenenhaus, Vinzi, Chatelin, and Lauro (2005). It is evident from Table 4 that the Chi-square (CMIN/DF) was 2.332, falling below the recommended threshold of 3 (Chinomona, 2011). The Normed Fit Index was 0857, which exceeded the acceptable level of 0.800 suggested by Hooper, Coughlan, and Mullen (2008). 
Table 4. Model fit summary

\begin{tabular}{l|c:c|c}
\hline \multicolumn{1}{c}{ Model fit indices } & Acceptable threshold & Current study threshold & Decision: acceptable/unacceptable \\
\hline SRMR & - & 0.104 & Acceptable \\
\hline d_ULS & - & 3.535 & Acceptable \\
\hline d_G & - & 2.075 & Acceptable \\
\hline Chi-Square value: $\chi^{2 /(d f)}$ & $<3$ & $2.332(857.225 /$ df) & Acceptable \\
\hline Normed fit index (NFI) & 0.800 & 0.857 & Acceptable \\
\hline Goodness-of-fit index (GFI) & $>0.36$ & 0.421 & Acceptable \\
\hline
\end{tabular}

Following the formulae provided by Tenenhaus, Vinzi, Chatelin, and Lauro (2005), the global goodness-of-fit $(G o F)$ statistic for the research model was calculated using the equation:

$$
G o F=\sqrt{\overline{A V E} \cdot \overline{R^{2}}} .
$$

As reflected in Table 4, the calculated global goodness of fit $(G o F)$ is 0.421 , which exceeds the threshold of $G o F>0.36$ suggested by Wetzels, Odekerken-Schröder, and van Oppen (2009). Thus, it can be concluded that the research model has a good overall fit, since the results of the fit indices of the initial assessment of the measurement model of all the manifest variables and their indicators were all acceptable as presented in Table 4. Thus, the findings from the measurement model showed that the conceptual model was a depiction of the data collected for the study. Pungchompoo and Sopadang (2015) observed that, once a good fit is obtained for a hypothesized model, the path significance of each association in the research model and the variance ought to be estimated. The path modelling, and its hypotheses testing are interpreted in the next section.

The coefficient of determination ( $R^{2}$ value) for each of the endogenous constructs in the structural model is presented in Table 5. It is evident that the $R^{2}$ values range from 0.053 to 0.598 , and $R^{2}$ values of 0.75 are considered to be substantial with significant predictive power, 0.50 moderate with modest predictive power and 0.25 weak with poor predictive power. It is evident from the results that the exogenous constructs linked to Start Up Awareness (SUA) - Management Skills (MS) account for $59.8 \%$ of the variance, while GF, CF and PSF accounted respectively for 5.3\%, $14 \%$ and $17.9 \%$. of the variance in this construct. Therefore, the predictive power of these determinants in the current study is considered to be ranging from weak to moderate.
Table 5. Coefficient of determination $\left(R^{2}\right)$

\begin{tabular}{l|c|c}
\hline Variables & $\boldsymbol{R}$-square $\left(\boldsymbol{R}^{\mathbf{2}}\right)$ & $\begin{array}{c}\boldsymbol{R} \text {-square }\left(\boldsymbol{R}^{\mathbf{2}}\right) \\
\text { adjusted }\end{array}$ \\
\hline CF & 0.140 & 0.122 \\
\hline$G F$ & 0.053 & 0.033 \\
\hline$M S$ & 0.598 & 0.594 \\
\hline$P S F$ & 0.179 & 0.162 \\
\hline
\end{tabular}

In assessing collinearity, the following sets of exogenous and endogenous constructs were analyzed, namely, SUA $\rightarrow$ CF; SUA $\rightarrow$ GF; SUA $\rightarrow$ MS; SUA $\rightarrow P S F ; M S \rightarrow C F ; M S \rightarrow G F$ and $M S \rightarrow P S F$. It is evident from the results contained in Table 6 that none of the variance inflation factor (VIF) values exceed the maximum threshold of 5, which would indicate critical levels of collinearity. Therefore, with VIF values only ranging between 1.000 and 2.488 , collinearity among the exogenous constructs is not an issue to be considered when further evaluating the model.

Table 6. VIF results in the structural model

\begin{tabular}{l|c:c:c:c|c}
\hline Research constructs & CF & GF & MS & PSF & SUA \\
\hline CF & - & - & - & - & - \\
\hdashline GF & - & - & - & - & - \\
\hdashline MS & 2.488 & 2.488 & - & 2.488 & - \\
\hdashline PSF & - & - & - & - & - \\
\hline SUA & & - & & - \\
\hline
\end{tabular}

Note: ${ }^{* *}$ Correlation is significant at the 0.01 level (2-tailed). SUA = star-up awareness, $\mathrm{MS}=$ management skills, PSF = personal/social source of finance, $\mathrm{GF}=$ government source of finance, $C F=$ corporate source of finance.

\subsection{Structural model assessment and hypotheses testing}

Figure 1 is an illustration of the structural model also known as the path model, which depicts the results of the hypotheses tested. In the structural model, Start-Up Awareness is depicted to have direct effects on Management Skills (MS), Government Finance (GF), Corporate Finance 
Table 7. Hypothesis test results

\begin{tabular}{|c|c|c|c|c|c|}
\hline $\begin{array}{l}\text { Proposed hypothesis } \\
\text { relationship }\end{array}$ & Hypothesis & Path coefficients & $T$-statistics & $P$-values & Rejected/Supported \\
\hline $\mathrm{SUA} \rightarrow \mathrm{MS}$ & $\mathrm{H} 1$ & 0.773 & 21.777 & 0.000 & Supported and significant \\
\hline SUA $\rightarrow$ PSF & $\mathrm{H} 2$ & 0.180 & 0.961 & 0.339 & Supported but insignificant \\
\hline $\mathrm{SUA} \rightarrow \mathrm{GF}$ & $\mathrm{H} 3$ & 0.269 & 2.669 & 0.009 & Supported and significant \\
\hline $\mathrm{SUA} \rightarrow \mathrm{CF}$ & $\mathrm{H} 4$ & 0.145 & 1.167 & 0.246 & Supported but insignificant \\
\hline $\mathrm{MS} \rightarrow \mathrm{PSF}$ & $\mathrm{H} 5$ & 0.547 & 3.600 & 0.000 & Supported and significant \\
\hline $\mathrm{MS} \rightarrow \mathrm{GF}$ & $\mathrm{H} 6$ & 0.053 & 0.381 & 0.704 & Supported but insignificant \\
\hline $\mathrm{MS} \rightarrow \mathrm{CF}$ & $\mathrm{H} 7$ & 0.250 & 2.047 & 0.043 & Supported and significant \\
\hline
\end{tabular}

Note: SUA = star-up awareness, MS = management skills, PSF = personal/social source of finance, GF = government source of finance, $\mathrm{CF}=$ corporate source of finance. Levels of significance: $p<0.05, t>1.96$.

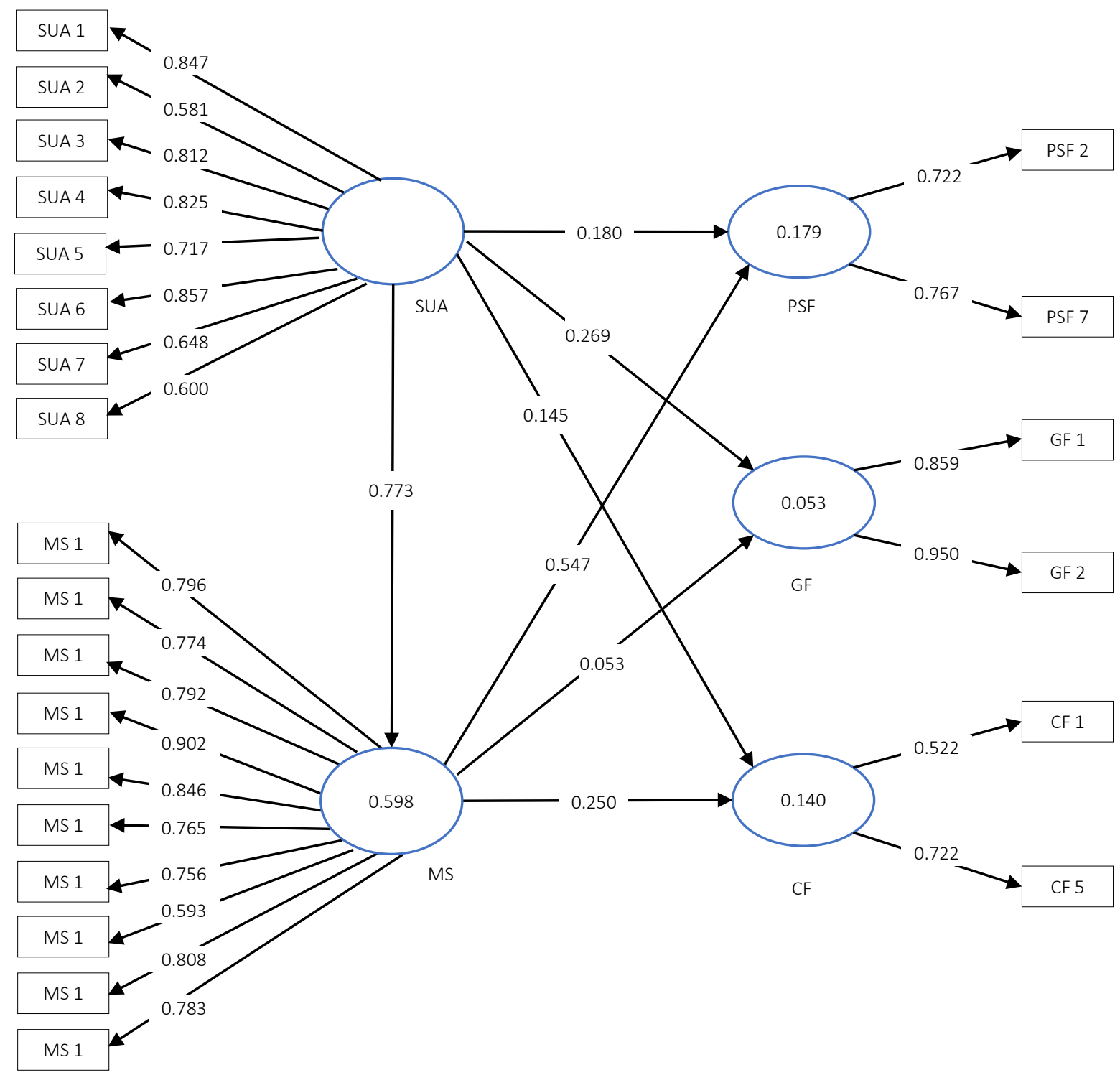

Note: SUA = star-up awareness, MS = management skills, PSF = personal/social source of finance, GF = government source of finance, $\mathrm{CF}=$ corporate source of finance.

Figure 1. Structural model results 
(CF) and Personal/Social Network (PSF). Table 7 provides the results of structural model path coefficients, and the significant results. The results of the path coefficient, the interpretation of the stated hypotheses with their corresponding factor loadings, the probability value ( $P$-value), as well as the outcome of their respective relationships are also presented in Table 7 provided.

It is clear from Table 7 that, while all proposed hypotheses are supported, only four are significant. In assessing the probability or the $P$-value, it was observed that six of the hypotheses were significant at the level of 0.05 as shown in Table 7. The summary of the hypothesized relationships is presented in the path diagram in Figure 1.

\section{DISCUSSION OF THE FINDINGS}

The results indicate that Start-up Awareness has a strong positive and significant effect on Management Skills $(\beta=0.773, t=21.77, p$-value $=0.00$ ), which implies that start-up awareness in South Africa can possibly explain about $77.3 \%$ of the entrepreneur's desire to acquire management skills that are necessary for their small enterprises to succeed. The results are consistent with the study done by Katwalo (2010), who stated that the relationship between managerial competency and critical success factor development is an avenue for achieving sustainable micro and small enterprises in Africa.

The results also reveal that Start-up Awareness has a weak positive but insignificant effect on Personal or Social Network source of finance $(\beta=0.180, \quad t=0.961, \quad p$-value $=0.339)$, which means that start-up awareness in SA can possibly explain about $18 \%$ of the entrepreneur's desires to utilize personal or social sources of finance. These results are supported by Smit and Watkins (2012, p. 6326) who pointed out that a lack of credit is also a major constraint experienced by emerging African SMEs, who depend on personal savings or loans from relatives and friends, as their main source start-up capital.

It also became evident that Start-up Awareness has a relatively strong positive and significant effect on the choice of Government as a source of enterprise finance by entrepreneurs $(\beta=0.269$, $t=2.669, p$-value $=0.009$ ). This finding implies that start-up awareness in SA can possibly explain about $26.9 \%$ of the entrepreneurs' desire to choose government as the first source of enterprise finance, compared to personal/social finance $(\beta=0.180, t=0.961, p$-value $=0.339)$ and corporate finance $(\beta=0.145, t=1.167, p$-val$\mathrm{ue}=0.246$ ), respectively. The results are consistent with that reported by Fatoki and Garwe (2012), who found that managerial skills significantly positively impact the SME start-ups' access to government funding.

The findings also reveal that Start-up Awareness has a relatively weak positive and insignificant effect on the entrepreneurs' desires to choose the Corporate (e.g., banks) as a source of finance $(\beta=0.145, t=1.167, p$-value $=0.246)$, compared to government finance $(\beta=0.269, t=2.669$, $p$-value $=0.009)$ and personal $/$ social source of funding $(\beta=0.180, t=0.961, p$-value $=0.339)$. This finding means that start-up awareness in SA can possibly explain about $14.5 \%$ of the entrepreneurs' considered choice of the corporate as a source of finance. The results are supported by previous studies conducted by Fatoki and Garwe, (2010), where it was reported that prior market research and related factors significantly positively impact accessibility by SME startups to different types of bank funding.

It was also ascertained that management skills have a stronger positive and significant effect on the entrepreneurs' decision to choose their Personal or social networks as a possible source of finance $(\beta=0.547, t=3.600, p$-value $=0.00)$, compared to corporate finance $(\beta=0.250$, $t=2.047, p$-value $=0.043)$ and government finance $(\beta=0.053, t=0.381, p$-value $=7.04)$, respectively. This finding implies that management skills in SA can possibly explain about $25 \%$ of the entrepreneurs' choice of personal/social networks as a first source of finance of their enterprises. The results are consistent with the study done by Mariotti and Glackin (2012) who pointed out that priority when borrowing money from the inner circles of the family should be a business-like manner, honesty and openness about the potential and risks the business bears. 
Management skills have the weakest positive and insignificant effect on the choice of Government as a source of finance $(\beta=0.053, t=0.381$, $p$-value $=7.04)$, compared to personal/social finance $(\beta=0.547, t=3.600, p$-value $=0.00)$ and corporate finance $(\beta=0.250, t=2.047, p$-value $=0.043)$. This finding means that social influence in SA can possibly explain only about $5.3 \%$ of the entrepreneurs' desire to choose government as a source of finance. The results are consistent with Fatoki and Akinwumi (2010, p. 2768) who found that the determinants of business success relatively impact the accessibility of all types of financing for SME start-ups.

Finally, management skills have a relatively strong positive and significant effect on corporate finance $(\beta=0.250, t=2.047, p$-value $=0.043)$. Thus, entrepreneurs with management skills are likely to choose corporate finance as a second choice to personal/social network finance. This finding also implies that management skills in South Africa can possibly explain about $25 \%$ of the entrepreneurs' likely desires to choose the corporates such as banks as the alternative source of business finance. The results are consistent with Gomezelj (2013), who found that managerial competencies significantly and positively impact the accessibility to all bank financing to SME start-ups.

The statistical tests have shown that all the determinants of start-up business success do not equally impact access to external finance by SME start-ups. The Framework for access to external financing by SME start-ups comprises three components, namely Entrepreneurial Awareness, Business Process and Financing Options.

\section{ENTREPRENEURIAL AWARENESS}

Based on the findings, it became apparent that the first component of the Framework, namely, Entrepreneurial Awareness, is composed of start-up awareness and management skills. Start-up awareness comprises determinants such as market research, business strategy, business plan, amount and source of seed capital, and location. Management skills included general management, strategic management, financial management, communication and marketing skills. All of the aforementioned affected access to all types of sources of business financing.

At this stage, the business owner-manager should understand and apply the different key determinants of a successful start-up, by equipping him/herself with the necessary knowledge of the industry in which he/she wants to start the business, as well as the necessary management skills that will enable him to operate and function effectively. Therefore, the achievement of the key determinants of a successful start seems critically important at the start-up stage.

\section{FINANCING OPTIONS}

The third component of the Framework comprises three types of external finance, namely, Government finance, bank finance (corporate source) and private equity (personal/social) finance. The financing option will depend on which requirements the business start-up entrepreneur can meet.

Figure 2 encapsulates in diagrammatic form the proposed framework recommended for start-up SMEs to access external finance. 


\section{ENTREPRENEURIAL AWARENESS}

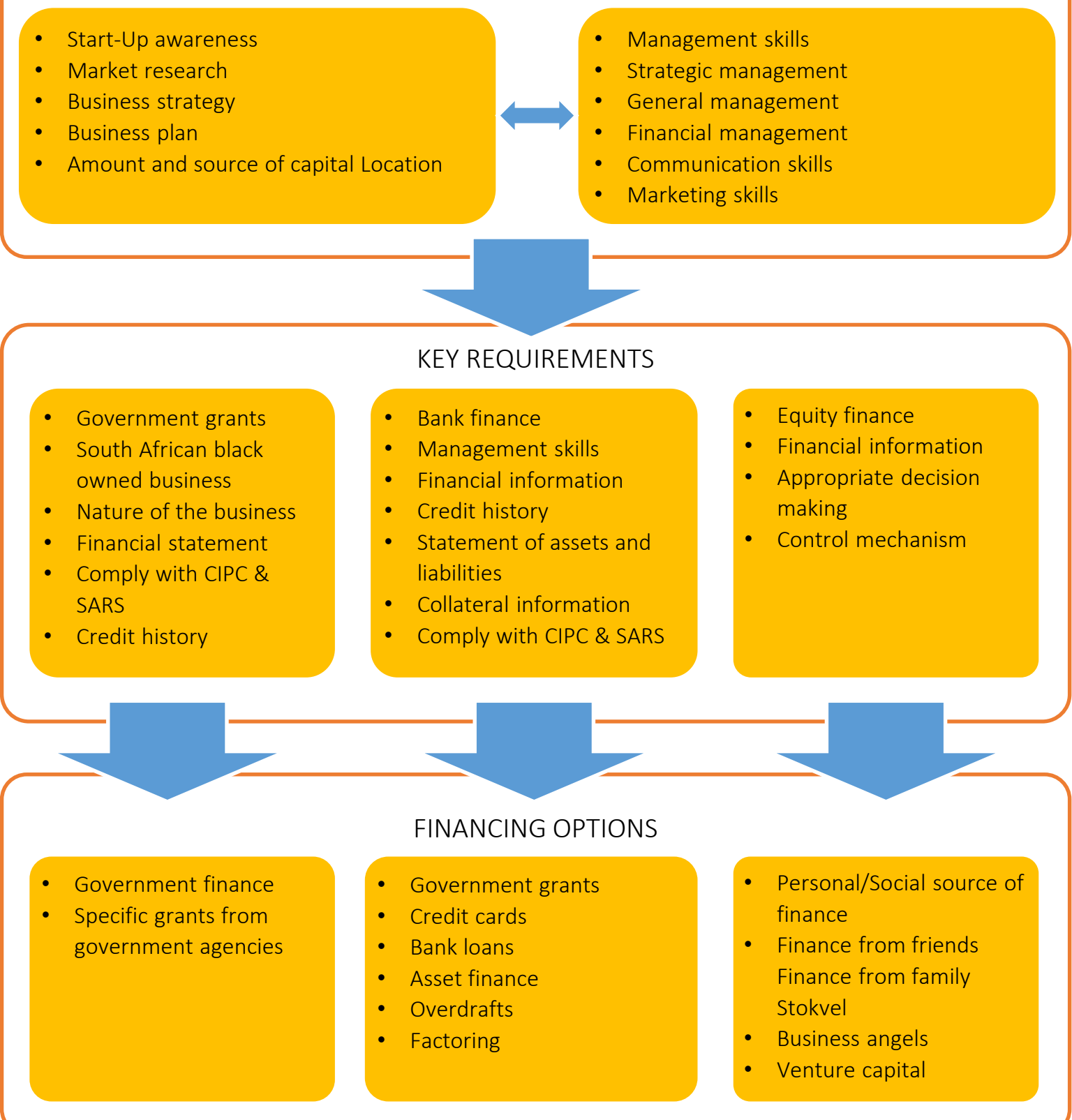

Figure 2. Financing framework for SME's access to external finance

\section{CONCLUSION}

SMEs are the major driving force of economic activity in any country, yet they face financing constraints. Therefore, there is a need to understand the financing preferences of SMEs and develop policies and strategies to alleviate the situation. The study found that the majority of the start-up SMEs are aware of external funding sources, however, the greatest challenge to accessing these funding is the complicated application procedure for both government grands and bank financing, followed by the bank interest rates that are generally perceived as high despite the bank or the sector of the business. 
The proposed Framework will contribute to addressing the aforementioned challenge faced by SMEs in general, and start-ups in particular. By understanding and utilizing the Financing Framework, SME start-ups would be able to plan their financing needs and choose from among three main sources of external finance. The acquisition of relevant vocational, technical and business skills is generally regarded as a source of competitive advantage for start-up SMEs. In addition, entrepreneurial awareness is seen as particularly important in enabling South African SMEs to advance from survivalist activities to larger and better earning enterprises.

\section{RECOMMENDATIONS}

It is strongly recommended that business owner-managers understand the determinants of business awareness and requisite management skills in order to improve their ability to access external finance. During the start-up process of business, the entrepreneur must be aware of the business opportunity, as without an opportunity there is no sustainable business potential. In an effort to gain a competitive advantage, differentiation of the business must be highlighted, the business model formulated, and the strategy clearly defined. A business plan weaving all these determinants must be developed in order to understand, among other things, the amount of seed capital required and from where to source the required capital.

To sustain and grow the business, the entrepreneur should consider that general management experience is of vital, as is strategic management. A lack of technical skills can also cause failure of a start-up business, although this can be resolved through the employment of suitably qualified staff. However, the entrepreneur could still be at a disadvantage if he is totally dependent on staff, most specifically during the early stages of the business. A lack of understanding of financial management and poor financial management can also be a contributory reason in the demise of the business. A lack of leadership skills can be crucial in a SME, where the entrepreneur might be the only manager in the enterprise, leading to poor management of staff. This problem can be exacerbated by poor communication both internally and externally. Similarly, uncontrolled growth, together with poor financial and inventory control, are also major contributors to business failure. Marketing skills are critical to the success of every business, as are contingency management skills, which allow the owner-manager to adapt to ever changing circumstances. Most of all, the entrepreneur must be desirous of growth.

Banks should develop mature relationships with start-up SMEs and increase the availability of finance to these SMEs. Banks should be able to assess SME finance applications based on the determinants of the business success. Like commercial banks, private equity finance providers should also place emphasis on the determinants while evaluating start-up SMEs financing applications.

In addition, financial institutions and other providers should design special schemes for SME start-ups to cater for their specific financial needs, because most SME start-ups will not meet the requirements for funding of most providers if they use the conventional evaluation system. The government of SA in collaboration with finance providers should institute interest subsidies for SME start-ups based on their potential to succeed. This will make it less burdensome for such businesses, particularly younger ones, to access external finance.

\section{REFERENCES}

1. Abor, J., \& Quartey, P. (2010). Issues in SME Development in Ghana and South Africa. International Research Journal of Finance and Economics, 39, 218-228. Retrieved from https:// www.researchgate.net/publication/270758190_Issues_in_SME_
Development_in_Ghana_and South_Africa

2. Abraham, S. (2013). Will business model innovation replace strategic analysis? Strategy \& Leadership, 41(2), 31-38. https://doi. org/10.1108/10878571311318222
3. Ayandibu, A. O., \& Houghton, J. (2017). The role of Small and Medium Scale Enterprise in local economic development (LED). Journal of Business and Retail Management Research, 11(2), 133-139. Retrieved from https://www.researchgate.net/ 
publication/316583604_The_role_ of_Small_and_Medium_Scale_ Enterprise_in_Local_Economic_ Development_LED

4. Beck, T. (2007). Financing constraints of SMEs in developing countries: the evidence, determinants and solutions. Retrieved from https:// econpapers.repec.org/paper/ tiutiutis/85aac075-08b5-44ce-bfla96b2a50b64a6.htm

5. Bisseker, C. (2014). SMEs: Stop the failure rate. Retrieved from http://www.financialmail.co.za/features/2014/05/15/smes-stop-thefailure-rate (accessed on December 31, 2015).

6. Blackburn, R. A., Hart, M., \& Wainwright, T. (2013). Small business performance: business, strategy and ownermanager characteristics. Journal of Small Business and Enterprise Development, 20(1), 8-27. https://doi. org/10.1108/14626001311298394

7. Bongini, P., Ferrando, A., Rossi, E., \& Rossolin, M. (2017). Suitable or non-suitable? An investigation of Eurozone SMEs access to marketbased finance. University of MilanBicocca, School of Economics and Statistics \& European Central Bank. Retrieved from https://cepr.org/ sites/default/files/Rossi $\% 2 \mathrm{C} \% 20$ Emanuele\%20paper.pdf (accessed on December 20, 2017).

8. Braun, M., Latham, S., \& Porschitz, E. (2016). All together now: strategy mapping for family businesses. Journal of Business Strategy, 37(1), 3-10. https://doi. org/10.1108/JBS-12-2014-0154

9. Burke, R. (2006). Entrepreneur's toolkit. UK, Burke publishing.

10. Carlson, K. D., \& Herdman, A. O. (2012). Understanding the Impact of Convergent Validity on Research Results. Organizational Research Methods, 15(1), 17-32. https://doi.org/10.1177\%2F1094428110392383

11. Chawla, S. K., Khanna, D., \& Chen, J. (2010). Are Small Business Critical Success Factors Same in Different Countries? Journal of Management, 7(1),
1-12. Retrieved from https:// web.b.ebscohost.com/abstract?direct $=$ true $\&$ profile $=$ ehost $\&$ scope $=$ sit e\&authtype $=$ crawler\&jrnl $=097429$ 56\&AN=57489757\&h=1guTVZe3 \%2bNcZxAudE6k\%2bxMrtP9Cu3 2u2SRvNDBsiNdboTNORHHpo 1 duW9OisKMnQSFzu4QJYpDiOC m04\%2bDUpdw\%3d\%3d\&crl=c\& resultNs $=$ AdminWebAuth\&result Local=ErrCrlNotAuth\&crlhashurl $=$ login.aspx $\% 3$ fdirect $\% 3$ dtrue $\% 26$ profile $\% 3$ dehost $\% 26$ scope $\% 3$ dsite \%26authtype\%3dcrawler\%26jrnl\% 3d09742956\%26AN\%3d57489757

12. Chell, E. (2013). Review of skill and the entrepreneurial process. International Journal of Entrepreneurial Behaviour \& Research, 19(1), 6-31. https://doi. org/10.1108/13552551311299233

13. Chinomona, R. (2011). Nonmediated channel powers and relationship quality: A case of SMES in Zimbabwe channels of distribution (Unpublished Ph.D. thesis). National Central University, Taiwan.

14. Coeuré, B. (2013). SME financing, market innovation and regulation. European Central Bank. Retrieved from http://www.ecb.europa. eu/press/key/date/2013/html/ sp130411.en.html (accessed on August 18, 2015).

15. Domeher, D., Abdulai, R., \& Yeboah, E. (2016). Secure property right as a determinant of SME's access to formal credit in Ghana: dynamics between Micro-Finance Institutions and Universal Banks. Journal of Property Research, 33(2), 162-188. https://doi.org/10.1080/0 9599916.2016.1160948

16. Doom, C., Milis, K., Poelmans, S., \& Bloemen, E. (2009). Critical success factors for ERP implementations in Belgian SMEs. JEIM, 23(3), 378-406. https://doi. org/10.1108/17410391011036120

17. European Central Bank. (2016). Survey on the Access to Finance of Enterprises in the euro area.

18. Fatoki, O., \& Garwe, D. (2010). Obstacles to the growth of new SMEs in South Africa: A principal component analysis approach. African Journal of Business Management, 4(5), 729-738. Retrieved from https:// www.researchgate.net/publication/267553799_Obstacles_to_ the_growth_of_new_SMEs_in_ South_Africa_A_principal_component_analysis_approach

19. Fatoki, O., \& Odeyemi, A. (2010) The determinants of access to trade credit by new SMEs in South Africa. African Journal of Business Management, 4(13), 2763-2770. Retrieved from https:// www.researchgate.net/publication/228973643_The_determinants_of_access_to_trade_credit_ by_new_SMEs_in_South_Africa

20. Fatoki, O., \& Odeyemi, A. (2010). Which New Small and Medium

Enterprises in South Africa Have Access to Bank Credit? International Journal of Business and Management, 5(10), 128-136. https://doi.org/10.5539/ijbm. v5n10p128

21. Fornell, C., \& Larcker, D. F. (1981). Evaluating Structural Equation Models with Unobservable Variables and Measurement Error. Journal of Marketing Research, 18(1), 39-50. https://doi. org/ $10.2307 / 3151312$

22. Fraering, M., \& Minor, M. S. (2006). Sense of community: an exploratory study of US consumers of financial services. International Journal of Bank Marketing, 24(5), 284-306. https://doi. org/10.1108/02652320610681738

23. Ghezzi, A. (2013). Revisiting business strategy under discontinuity. Management Decision, 51(7), 1326-1358. https:// doi.org/10.1108/MD-05-20120388

24. Greene, L. C. (2012). Entrepreneurship ideas in action (5th ed.). South Western, Cengage Learning.

25. Hair, J. F., Black, B., Babin, B., Anderson, R. E., \& Tatham, R. L. (2006). Multivariate Data Analysis (6th ed.). USA: Pearson.

26. Hair, J. F., Black, W. C., Babin, B., \& Anderson, R. E. (2009). Multivariate Data Analysis: A 
Global Perspective (7th ed.). Upper Saddle River: Prentice Hall.

27. Hair, J. F., Black, W. C., Babin, B., \& Anderson, R. E. (2010). Multivariate Data Analysis (7th ed.). USA, Pearson.

28. Hooper, D., Coughlan, J., \& Mullen, M. R. (2008). Structural Equation Modelling: Guidelines for Determining Model Fit. Electronic Journal of Business Research Methods, 6(1), 53-60. https://doi.org/10.21427/D7CF7R

29. Katwalo, A. M. (2010). Competence and Critical Success Factor Development as an Avenue for Achieving Sustainable Micro and Small Enterprises in Africa. Journal of Management Policy and Practice, 11(5), 139-144. Retrieved from https://su-plus.strathmore. edu/handle/11071/3372

30. Kipkebut, D. J. (2010). Human Resource Management Practices and Organizational Commitment in Higher Educational Institutions: A Kenyan Case. The IUP Journal of Organizational Behavior, 9(1-2), 45-70. Retrieved from https://papers.ssrn.com/sol3/ papers.cfm?abstract_id $=1581263$

31. Kline, R. B. (2011). Principles and Practice of Structural Equation Modeling. USA: Guilford Publications.

32. Kumar, S., \& Rao, P. (2016). A conceptual framework for identifying financing preferences of SMEs. Small Enterprise Research, 22(1), 99-112. https://doi.org/10.1 080/13215906.2015.1036504

33. Kwaak, T., \& Zeijden, P. Van Der. (2016). Survey on the access to finance of enterprises (SAFE).

34. Lai, C.-S., Chiu, C.-J., Yang, C.-F., \& Pai, D.-C. (2010). The Effects of Corporate Social Responsibility on Brand Performance: The Mediating Effect of Industrial Brand Equity and Corporate Reputation. Journal of Business Ethics, 95(3), 457-469. http:// dx.doi.org/10.1007/s10551-0100433-1

35. Lekhanya, L. M. (2016). Determinants of survival and growth of small and medium enterprises in rural KwaZulu Natal (Unpublished Ph.D. Thesis). University of Western Cape. Retrieved from https://etd.uwc. ac.za/xmlui/handle/11394/5569

36. Li, Y. (2015). SMEs and Entrepreneurial Finance in OECD Countries: Good Practice and Lessons Learned. Journal of Law and Governance, 10(2), 30-35. Retrieved from https:// web.a.ebscohost.com/abstract?dir ect $=$ true $\&$ profile $=$ ehost $\&$ scope $=s$ ite\&authtype $=$ crawler\&jrnl $=1833$ 4318\&AN=115790669\&h=b\%2fG VE0QzR8DUc9\%2b0oayeV1XQE KTyLkDK\%2f7LTrfhHDsrDlbofJ qWec\%2b1yBzcNTbuHdhQWQg t9AWF5oclf\%2b2qZRw\%3d\%3d $\& \mathrm{crl}=\mathrm{c} \&$ resultNs $=$ AdminWebAut h\&resultLocal=ErrCrlNotAuth\&c rlhashurl=login.aspx\%3fdirect $\% 3$ dtrue\%26profile\%3dehost\%26sco pe\%3dsite\%26authtype\%3dcrawl er\%26jrnl\%3d18334318\%26AN\% 3d115790669

37. Louw, L., \& Venter, P. (2013). Strategic management Developing sustainability in Southern Africa (3rd ed.). South Africa: Oxford University Press Southern Africa (Pty) Limited. Retrieved from https://trove.nla. gov.au/work/157104708

38. Manuel, T. A. (2012). Presidency \& National Planning Commission, South Africa's National Development Plan 2030. Retrieved from https://www.gov.za/issues/ national-development-plan-2030 (accessed on November 26, 2017).

39. Mazanai, M., \& Fatoki, O. (2012). Access to finance in the SME sector: A South African perspective. Asian Journal of Business Management, 4(1), 58-67. Retrieved from https:// www.semanticscholar.org/paper/ Access-to-Finance-in-the-SMESector\%3A-A-South-MazanaiFatoki/139075b26b6f6cd5a5785b0 3bd6b03f21f0522f9

40. Osano, H. M., \& Languitone, H. (2016). Factors influencing access to finance by SMEs in Mozambique: Case of SMEs in Maputo central business district. Journal of Innovation and Entrepreneurship, 5(13), 1-16. http://dx.doi.org/10.1186/s13731016-0041-0

41. Osano, H. M., \& Languitone, H. (2016). Factors influencing access to finance by Pietermaritzburg Chamber of Business. Retrieved from https://innovation-entrepreneurship.springeropen.com/articles/10.1186/s13731-016-0041-0

42. Pietermaritzburg Tourism. (2016). Pietermaritzburg Fact File. Retrieved from http://www. pietermaritzburgtourism.co.za/ facts.html (accessed on October $28,2016)$

43. Pungchompoo, S., \& Sopadang, A. (2015). Confirmation and evaluation of performance measurement model for the Thai frozen shrimp chain. Business Process Management Journal, 21(4), 837-856. https://doi. org/10.1108/BPMJ-06-2014-0053

44. Ramayah, T., Lee, J. W. C., \& In, J. B. C. (2011). Network collaboration and performance in the tourism sector. Service Business, 5(4), 411-428. https://doi. org/10.1007/s11628-011-0120-Z

45. Rupeika-Apoga, R., \& Solovjova, I. (2017). Access to Finance for Latvian SMEs. European Research Studies Journal, 20(3A), 57-68. Retrieved from https://ideas. repec.org/a/ers/journl/vxxy2017i3ap57-68.html

46. Schiraldi, H., \& Silva, J. (2012). Writing a business plan: reference tools to assist budding entrepreneurs. Reference Reviews, 26(8), 7-9. https://doi. org/10.1108/09504121211278016

47. Sedmak, M., \& Longhurst, P. (2010). Methodological choices in enterprise systems research. Business Process Management Journal, 16(1), 76-92. https://doi. org/10.1108/14637151011017958

48. Short, J. C., Ketchen, D. J., Shook, C. L., \& Ireland, R. D. (2010). The Concept of "Opportunity" in Entrepreneurship Research: Past Accomplishments and Future Challenges. Journal of Management, 36(1), 40-65. https://doi.org /10.1177\%2F0149206309342746

49. Simpson, M., Padmore, J., \& Newman, N. (2011). Towards 
a new model of success and performance in SMEs. IJEBR, 18(3), 264-285. https://doi. org/10.1108/13552551211227675

50. Smit, Y. (2012). A structured approach to risk management for South African SMEs, Cape Peninsula University of Technology. Retrieved from http://etd.cput.ac.za/bitstream/ handle/20.500.11838/1726/structured $\% 20$ approach $\% 20$ to $\% 20$ risk $\% 20$ management $\% 20$ for $\% 20$ SA\%20SMEs.pdf? sequence $=1$ (accessed on January 5, 2018).

51. Smorfitt, W. R. (2008). A critical assessment of the impact of interventions to stimulate the establishment and growth rates of SMEs in the formal sector in KwaZulu-Natal 1994-2008. (Unpublished Ph.D. Thesis). University of KwaZulu-Natal, Pietermaritzburg. Retrieved from https://pdfs.semanticscholar.org/3027/c89af77548e79a24eee3526e744eedefeb05.pdf

52. Statistics South Africa (2016). Msunduzi. Retrieved from http://www.statssa.gov.za/?page_ $\mathrm{id}=993 \& \mathrm{id}=$ the - msunduzi municipality (accessed on August $25,2016)$.
53. Storey, D. J., \& Greene, F. J. (2010). Small business and entrepreneurship. England: Pearson Education Limited.

54. Teece, D. J. (2010). Business Models, Business Strategy and Innovation. Long Range Planning, 43(2-3), 172-194. https://doi. org/10.1016/j.lrp.2009.07.003

55. Tenenhaus, M., Vinzi, V. E., Chatelin, Y., \& Lauro, C. (2005). PLS Path Modeling. Computational Statistics \& Data Analysis, 48(1), 159-205. https:// doi.org/10.1016/j.csda.2004.03.005

56. The World Bank Task Team. (2017). The World Bank in South Africa. Retrieved from http:// www.worldbank.org/en/country/ southafrica/overview (accessed on January 20, 2018).

57. Urbach, N., \& Ahlemann, F. (2010). Structural Equation Modeling in Information Systems Research Using Partial Least Squares. Journal of Information Technology Theory and Application (JITTA), 11(2). Retrieved from https://www.researchgate.net/ publication/228467554_Structural_equation_modeling_in_information_systems_research_using_Partial_Least_Squares

58. Uyar, A., \& Guzelyurt, M. K. (2015). Impact of firm characteristics on capital structure choice of Turkish SMEs. Managerial Finance, 41(3), 286-300. https://doi.org/10.1108/ MF-01-2014-0016

59. Vicente, M., Abrantes, J. L., \& Teixeira, M. S. (2015) Measuring innovation capability in exporting firms: the INNOVSCALE. International Marketing Review, 32(1), 29-51. https://doi. org/10.1108/IMR-09-2013-0208

60. Wagner, E. T. (2015). Five Reasons 8 Out Of 10 Businesses Fail. Retrieved from http://www.forbes. com/sites/ericwagner/2013/09/12/ five-reasons-8-out-of-10-businesses-fail/ (accessed on December 30, 2015).

61. Wetzels, M., Odekerken-Schroder, G., \& Oppen, C. (2009). Using PLS Path Modeling for Assessing Hierarchical Construct Models: Guidelines and Empirical Illustration. MIS Quarterly, 33(1), 177-195. https://doi. org/10.2307/20650284

62. World Bank (2003). Pilot investment assessment: Mozambique industrial performance and investment climate. Maputo: CTA/CPI/ RPED/APSG/WB. 